\title{
自己位置推定のための散策型ロボットによる電子タグ埋設位置推定*
}

\author{
千田陽 介*1, 財 部 修 平*2 \\ 木室義 彦*3, 長谷川勉*4
}

\section{Localization of Unknown Placed RFID Tags Using Nomadic Robots}

\author{
Yosuke SENTA*5, Shuhei TAKARABE, \\ Yoshihiko KIMURO and Tsutomu HASEGAWA \\ ${ }^{* 5}$ Institute of Systems \& Information Technologies/KYUSHU, \\ 2-1-22 Momochihama, Sawara-ku, Fukuoka-shi, Fukuoka, 814-0001 Japan
}

\begin{abstract}
Self-localization of the mobile robot using RFID system generally requires a lookup table which relates the ID of each tag with its position. However, it is tedious for a human worker to manually build the table. This paper proposes a method to automatically build the lookup table by a simple mobile robot without global position measurement function. Given the small number of RFID tags with their accurate position data, the method succeefully build the lookup table for many other RFID tags whose position is unknown in advance.
\end{abstract}

Key Words : RFID Tag, Positioning, Moving Robot, Measurement, Localization

\section{1. は じめに}

移動ロボットの自己位置推定に電子タグ (以下“夕 グ”) システムを用いる研究が為されている．最もシン プルな方法は, タグが埋設された床面上をタグリーダ (以下 “リーダ”) を持ったロボットが走行し, 読取れた タグの埋設位置を自己位置とするものである(1). しか しタグが読取れる範囲はある程度の広がりがあるため, この方法は十分な精度が得られない，そのため，レー ザやカメラなど他のセンサと併用するもの ${ }^{(2)}(3)$, リー ダを複数用いるもの ${ }^{(4)}$, 複数のタグを同時に読取る特 殊なリ一ダを用いるもの ${ }^{(5)}$ ，ロボットやリーダを移動 させるもの ${ }^{(6) \sim(8)}$ など, 様々な手法が研究されている. いずれの手法でも, ロボットはタグの埋設位置をあら かじめ知っておく必要がある。これには，夕グ ID と 埋設位置の対応を表す参照テーブルを用いる方法 ${ }^{(1)}$, タグ自身に埋設位置を格納しておく方法 ${ }^{(4)}{ }^{(6)}$, 機械 学習を用いて教師データの中に組み込む方法 (7) (8) な どがある.このうち，参照テーブルを用いる方法と夕 グに位置を格納する方法は, デー夕を間接的に引き出 すか直接的に引き出すかの違いのみで，ほとんど同じ である、また，機械学習を用いる方法も，参照テーブル を用いてシミュレーションで教師データを作ることが

* 原稿受付 2008 年 4 月 2 日

*1 正員, (財)九州システム情報技術研究所(焉814-0001 福岡 市早良区百道浜 2-1-22).

*2 九州大学大学院システム情報科学研究院 (畐 819-0385 福岡 市西区元岡 744).

*3 (財) 九州システム情報技術研究所.

*4 正員, 九州大学システム情報科学研究院.

E-mail : senta@isit.or.jp
できる ${ }^{(8)}$ ，そのため, タグを用いたロボットの自己位 置推定では, 参照テーブルが非常に重要となる.

一方, タグシステムは生産, 物流, 医療, 観光, 展示, 介護, 福祉など, 様々な分野で利用されてきている.こ のため, ロボット管理者以外の者も環境内にタグを埋設 していくと予想される.タグの通信規格は ISO14443, 15693, 18000 などによって標準化されているため, 第 三者が埋設したタグも読取ることができる.ロボット の自己位置推定において,これらのタグも利用するこ とが出来れば, 位置推定精度の向上やタグ設置コスト の低隇が期待できる.しかし、これら第三者が埋設し たタグは埋設位置が不明である.これらのタグを利用 するためには, 環境内の夕グを探り当て参照テーブル に登録しなければならない。

この作業を人手で行うことは非現実的であり，自動 化が必要である、筆者らは, この自動化に関して

i. タグ探索専用のロボットを少数作る.

ii. このロボットで環境内のタグの埋設位置を正確に 推定させ, 参照テーブルを得る.

iii. i. 以外の多数のロボットが ii. の参照テーブルを活 用して自己位置推定を行う.

というシナリオで解決可能と考えている. しかし, 利 用頻度が低いi．の専用ロボットを作ることはコストパ フォーマンスが悪い. また, タグの埋設位置を正確に 推定するには時間がかかるため, 作業中のロボットが 邪魔になることも予想される。 そこで筆者らは, 清掃 
や警備など，もともと環境内を広くかつ満遍無く移動 するロボットをi．の専用ロボットの代わりとして利用 し,その本来の作業を実行する傍ら ii.の夕グの探索を 行わせることを考えている.すなわちロボットは夕グ の埋設位置の推定のために停止や方向転換をせず, あ くまで本来の作業を遂行するものである. 専用ロボッ 卜を用いるのに比べ, 参照テーブルが得られるまで時 間がかかるが, 追加コストはわずかまたはゼロである.

環境内を満遍無く移動するロボットの中には, セン サを多数搭載し自己位置推定の機能を持つものもある. 筆者らは, 既にそのような自己位置推定可能な高機能 ロボットを利用してタグの埋設位置推定を行う研究を 行った ${ }^{(9)}$. しかし市販の家庭用掃除ロボットのように 自己位置推定機能を持たない低機能なロボットも存在 する. 本論文は, このような低機能ロボットが, ロボッ 卜管理者が埋設した少数の位置既知の夕グを手がかり に, 第三者が埋設したタグの参照テーブルを作る手法 について述べるものである.

\section{2. 散策型ロボットによるタグ埋設位置推定}

$2 \cdot 1$ タグ探索ロボットタグの位置推定を行う 低機能なロボットは, 市販の家庭用掃除ロボットをモデ ルにした.このロボットは壁に接触する度にランダム な角度で向きを変え, 直進を繰り返す動作を行う (10). 以後この動作を “散策”と呼ぶ.夕グ探索ロボットは, 壁との接触を知るバンパスイッチ, 左右の駆動輪の動 きを知るロータリエンコーダ, 床面に埋設されたタグ の ID を読取るリーダ,の三種類のセンサのみが搭載 されていると仮定する、ロボットはロータリエンコー ダを用いて, 移動中の二地点間の距離を得ることがで きる、等速直線運動中は減速機構のバックラッシの影 響を受けず, エンコーダのカウント值を直接読取るこ とで距離を得ることができるため, 精度が期待できる.

$2 \cdot 2$ 電子タグシステムの特性とタグ間距離の計測 タグには, 電池を内蔵し自ら電波を発するアクティブ 型と,リーダから電力を供給されて応答するパッシブ 型がある. 環境内に長期間タグを埋め込む場合, メン テナンス性からパッシブ型が選択されることが多い. そこで本論文でも，パッシブ型のタグを採用した．筆 者らは既に実験で用いるパッシブ型システム (TI 社 RI-K3A-001A，133.2kHz) について特性評価を行い， 特定の条件下では「一定周期で読取りを試みるリーダ と床面上の夕グが, 水平投影面で $91.5 \mathrm{~mm}$ 以内に近付 くと，確実にそのタグの ID を読取ることができる」 というシミュレーション用タグモデルを得ている(7). すなわち, リーダは半径 $R=91.5 \mathrm{~mm}$ 以内にタグが
存在しているか否かのみ知ることができる，以後,こ の $R$ を “夕グの応答半径”, 夕グから半径 $R$ の領域を “夕グの応答範团” と呼ぶ.なお,この応答半径の具体 的数值はシミュレーションのための標準値であり, 実 際は夕グの設置条件や個体差によって応答半径は一定 のバラツキが存在する. また, タグの応答範囲外でも 低い確率で夕グの ID が読取れることもある.この䛊 差の影響については, 後で議論する.

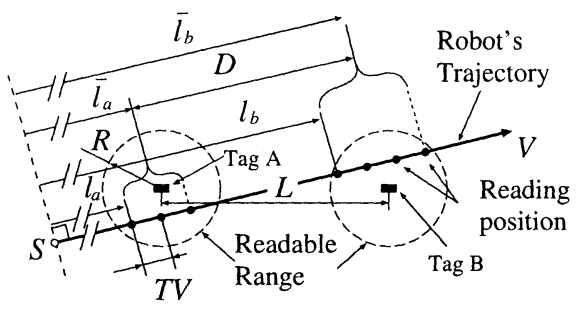

Fig. 1 Measuring of distance between tags

ダグ探索ロボットは, 直進動作中にタグ A の応答 範囲に入るとタグ A が検知できる. また，その時の エンコーダのカウント值から, 任意の位置 S からの距 離 $l_{a}$ を得ることができる，ただし，タグ読取り周期 $T$ がロボットの移動速度 $V$ に対し十分小さいと, 図 1 のように S からタグ $\mathrm{A}$ の応答範囲までの距離は, $l_{a}$, $l_{a}+T V, l_{a}+2 T V, \ldots$ と複数得られてしまう. そこで これらの平均 $\bar{l}_{a}$ を $\mathrm{S}$ とタグ $\mathrm{A}$ との距離とする. 同じ 直線運動中にタグ $\mathrm{B}$ に関しても $\mathrm{S}$ との距離 $\bar{l}_{b}$ が得ら れると,こ机らの差からタグ $\mathrm{AB}$ 間の距離 $D$ を求め ることができる.

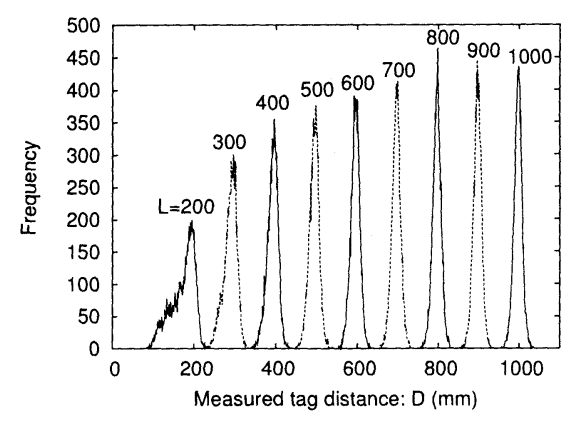

Fig. 2 Histograms of measured tag's distance

このタグ間距離 $D$ は, 二つのタグに対するロボット の進入角や， $T$ と $\mathrm{S}$ との関係からなる初期条件に依存 する、ロボットは散策によって, 異なった進入角のタグ 間距離 $D$ を幾つも得る. 図 2 は, 距離 $L$ 離れたタグ の計測距離 $D$ のヒストグラム (母数 10,000) で, ラン ダムな進入角や初期条件を用いてシミュレーションで 


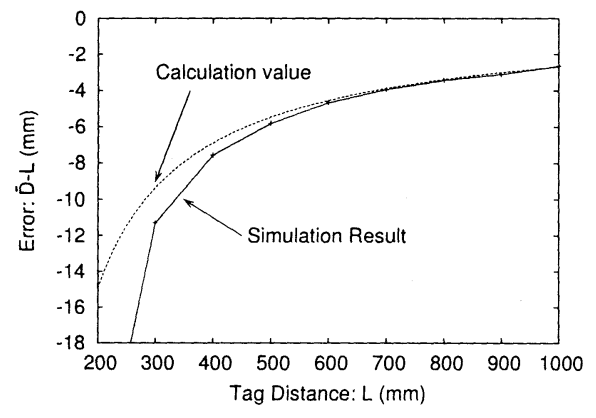

Fig. 3 Average error of measurement tag's distance

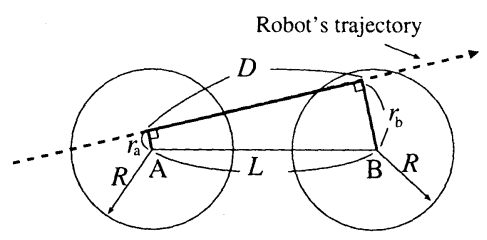

Fig. 4 Estimation of distance of two tags

求めたものである.この結果に対し， $D$ の平均 $\bar{D}$ と真 値 $L$ の差をとったものが図 3 中の Simulation Result のグラフである.これより L が小さけ机ば小さい程, $\bar{D}$ は真値より少なめになることが分かる. タグの読取 り周期 $T$ を無視すると, 計測距離 $D$ は図 4 の上うに ロボットの軌跡と垂直で, それぞれの夕グを通る直線 間の距離になる.ロボットの軌跡とタグ $\mathrm{A}, \mathrm{B}$ との距 離をそれぞれ $r_{a}, r_{b}$ とすると, $D$ は次のように表すこ とができる.

$$
D=\sqrt{L^{2}-\left(r_{a}-r_{b}\right)^{2}}
$$

進入角はランダムなため, $r_{a}, r_{b}$ は $-R \sim R$ の値を 取る。すなわち計浿距離の平均 $D_{\text {ave }}$ は $r_{a}, r_{b}$ をこの 区間で積分し, 積分幅で割った以下のような形に収束 する。

$$
\begin{aligned}
D_{\text {ave }} & =\int_{-R}^{R} \int_{-R}^{R} \frac{\sqrt{L^{2}-\left(r_{a}-r_{b}\right)^{2}}}{(2 R)^{2}} d r_{b} d r_{a} \\
& =\frac{\left(2 R^{2}+L^{2}\right) \sqrt{L^{2}-4 R^{2}}+3 L^{2} R \sin ^{-1} \frac{2 R}{L}-L^{3}}{6 R^{2}}
\end{aligned}
$$

図 3 で Calculation value と示されたグラフはこの 式を当てはめた結果で, シミュレーション結果と似て いる.

この結果を用い, タグ間距離を補正する方法も考え られる. しかし, タグの応答半径 $R$ は夕グの埋設状態 や個体差に依存する值である. 第三者が埋設したタグ の状態は不明という考えから, 今回は補正は行わない

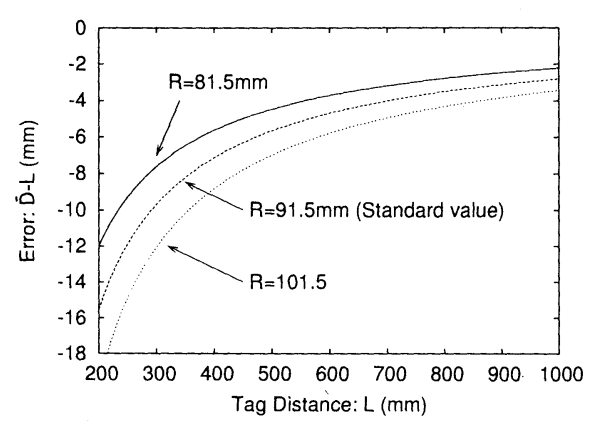

Fig. 5 Relation between measuremtnt tag's distance and a radius of readable range $R$.

こととした．またこのような埋設状態やタグの特性の バラッキによる $R$ の誤差が, 計測距離 $\bar{D}$ に与える影 響について調べるため, 式 (2) を用いて $R$ をシミュ レーションの標準値 $(91.5 \mathrm{~mm})$ から $\pm 10 \mathrm{~mm}$ 変化さ せた時の結果を図 5 に示す. 図のように $R$ の䛊差に よって生じる誤差は, 式 (2)によって記述される原理 的な誤差と比べて小さい.ささらに,この結果は両方の タグの応答半径が同様に誤差が発生した時のものであ り,片方のタグのみに誤差が発生した場合はこれより も変化が小さくなる.このことから, 夕グの応答半径 のバラツキが計測距離に与える影響はほとんど無いこ とが分かる.

2.3 タグ間距離を用いた埋設位置の推定 前節で はロボットが散策することで, 誤差を含む夕グ間距離 $\bar{D}$ が求められることを示した.この節では, 得られたタグ 間距離から, 䜋差を吸収し各多グの位置を求める手法に ついて述べる. 以下タグ $n$ の位置を $\boldsymbol{X}_{n}=\left(x_{n}, y_{n}\right)^{T}$, タグ $m$ と $n$ との計測距離を $\bar{D}_{m n}$, 予め埋設位置が与 えられたタグの集合を $K$, 位置が推定されたタグの集 合を $E$ (初期状態: $E=\emptyset$ ) と定義する.

2.3.1 未知のタグと既知のタグ間の距離が得られ た場合 未知のタグ $x \notin K \cup E$ と既知の夕グ $a \in K \cup E$ 間の距離 $\bar{D}_{a x}$ が得られた場合, まず以 下の 2 つの条件が満たされ, タグ $x$ の位置 $\boldsymbol{X}_{x}$ を求 めることができるかを確認する。

1. 既に既知のタグと $x$ との距離が 2 つ以上求めら れていること (2 つのタグを $b, c \in K \cup E$ とする)

2. $\bar{D}_{a x}, \bar{D}_{b x}, \bar{D}_{c x}, \boldsymbol{X}_{a}, \boldsymbol{X}_{b}, \boldsymbol{X}_{c}$ の誤羑が, $\boldsymbol{X}_{x}$ の 推定に大きな影響を与えない関係であること 今回, 2.の条件は経験的に以下のようにした.

- $\boldsymbol{X}_{a}, \boldsymbol{X}_{b}, \boldsymbol{X}_{c}$ を頂点とする三角形の各角が $20^{\circ} \sim$ $160^{\circ}$ の範囲にあること

- $\boldsymbol{X}_{a}, \boldsymbol{X}_{b}, \boldsymbol{X}_{c}$ 間それぞれの距離が, $\bar{D}_{a x}, \bar{D}_{b x}, \bar{D}_{c x}$ それぞれの 5 倍より大きいこと 
これら 1.2. の条件が満たされていた場合は, $\boldsymbol{X}_{a}$ ， $\boldsymbol{X}_{b}, \boldsymbol{X}_{c}$ を中心とした半径 $\bar{D}_{a x}, \bar{D}_{b x}, \bar{D}_{c x}$ の円 A, B, $\mathrm{C}$ の交点から $\boldsymbol{X}_{x}$ を求める(こ机により $x \in E$ とな る). ただし， $\boldsymbol{X}_{x}$ を得るのに用いたこれらの值も計測 値, 推定値であり，誤差を含む. そのため, 3 つの円が 1 点で交わる可能性は低い，そこで, 以下のように平 均を用いて $\boldsymbol{X}_{x}$ を計算した (図6).

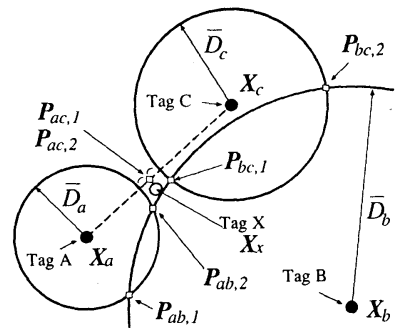

Fig. 6 Geometry of tag's layout

1. 円 A と B との交点 $\boldsymbol{P}_{a b, 1}, \boldsymbol{P}_{a b, 2}$ を求める. こ こで円 A, B が交わらない場合 $\left(\left|\boldsymbol{X}_{a}-\boldsymbol{X}_{b}\right|>\right.$ $\left.\bar{D}_{a x}+\bar{D}_{b x}\right)$ は, $\boldsymbol{X}_{a}, \boldsymbol{X}_{b}$ を結ぶ線分と, 円 $\mathrm{A}, \mathrm{B}$ それぞれとの交点の中点を共に $\boldsymbol{P}_{a b, 1}, \boldsymbol{P}_{a b, 2}$ と する.この点は以下の式で計算できる.

$$
\boldsymbol{X}_{a}+\frac{\boldsymbol{X}_{b}-\boldsymbol{X}_{a}}{2}\left(1-\frac{\bar{D}_{a x}+\bar{D}_{b x}}{\left|\boldsymbol{X}_{b}-\boldsymbol{X}_{a}\right|}\right)
$$

2. 同様に円 A と C の交点 $\boldsymbol{P}_{a c, 1}, \boldsymbol{P}_{a c, 2}$, 円 B と C の交点 $\boldsymbol{P}_{b c, 1}, \boldsymbol{P}_{b c, 2}$ を求める.

3. $i, j, k=1,2$ の組合せ (8 通り) に対し, 以下の値 を求める.

$$
\begin{aligned}
L_{i, j, k} & =\left|\boldsymbol{P}_{a b, i}-\boldsymbol{P}_{b c, j}\right|+\left|\boldsymbol{P}_{b c, j}-\boldsymbol{P}_{a c, k}\right| \\
& +\left|\boldsymbol{P}_{a c, k}-\boldsymbol{P}_{a b, i}\right|
\end{aligned}
$$

4. $L_{i, j, k}$ が一番小さかった $i, j, k$ を用いて,

$$
\boldsymbol{X}_{x}=\frac{\boldsymbol{P}_{a b, i}+\boldsymbol{P}_{b c, j}+\boldsymbol{P}_{a c, k}}{3}
$$

とする.

\subsection{2 既知のタグ間距離が追加，更新された場合} ロボットの散策により, 既知のタグ $i, j \in K \cup E$ が追 加, 更新された場合, 図 7 (a)のようにタグ $i, j$ 間に 自然長 $\bar{D}_{i j}$ の仮想的なバネが, $\left|\boldsymbol{X}_{i}-\boldsymbol{X}_{j}\right|$ に伸縮さ れて接続していると考え, 静的な釣合いの位置を求め る.ここでは単純に, すべての $i \in E$ に対し, 以下の ような運動方程式を解き, タグ $\boldsymbol{X}_{i}$ を収束させた (同 図(b))。

$$
\begin{aligned}
\boldsymbol{F}_{i} & =\sum_{j \in K \cup E} k\left(l_{i, j}-\left|\boldsymbol{X}_{i}-\boldsymbol{X}_{j}\right|\right) \frac{\boldsymbol{X}_{i}-\boldsymbol{X}_{j}}{\left|\boldsymbol{X}_{i}-\boldsymbol{X}_{j}\right|} \\
& =m \ddot{\boldsymbol{X}}_{i}+c \dot{\boldsymbol{X}}_{i}
\end{aligned}
$$

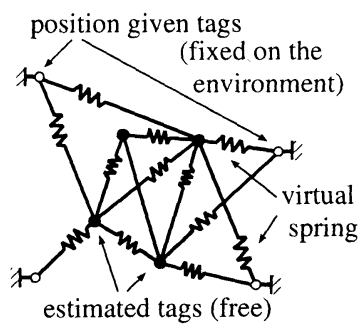

(a) Optimization by static equilibrium

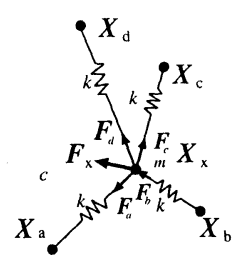

(b) solving by dynamics simulation
Fig. 7 Statics model for optimization of tag position

ここで, $m$ は夕グの仮想的な質量, $k$ はバネ定数, $c$ は 粘性摩擦係数である.

2.3.3 未知のタグ間の距離が得られた場合 未 知のタグ $x, y \notin K \cup E$ 間の距離 $\bar{D}_{x y}$ が得られた場 合, タグ位置の推定は行わない.この $\bar{D}_{x y}$ は保存して おき, 後にタグ $x$ もしくは $y$ の位置が $2 \cdot 3 \cdot 1$ 節の方法 で既知になるまで待ち, その時に未知の方の夕グの位 置推定に使う.

\section{3. シミュレーションと実機による検証}

$3 \cdot 1$ シミュレーション条件提案手法を検証す るため, シミュレーションシステムを構築した。図 8 に部屋のモデルを示す. 12 畳 $\left(19.44 \mathrm{~m}^{2}\right)$ の部屋の中 にタグを $30 \mathrm{~cm}$ 間隔で 216 個配置している. 原理上こ の配置はランダムでもかまわないが, 真値とのずれや その傾向を容易に知る目的で格子状としている.

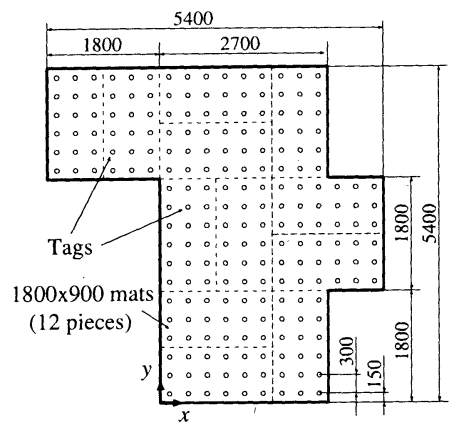

Fig. 8 Tag layout for simulation

ロボットの動きは文献 ${ }^{(10)}$ を参考に $0.3 \mathrm{~m} / \mathrm{s}$ の散策 動作とした. 図 9 は軌跡の一例である. また同文献に 従い,一回の清掃作業でロボットが進む道程は $900 \mathrm{~m}$ とした. 一方, 夕グ読取り周期 $T$ や, タグの応答半径 $R$ は実機に合わせ $T=0.1 \mathrm{~s}, R=91.5 \mathrm{~mm}$ とした. 


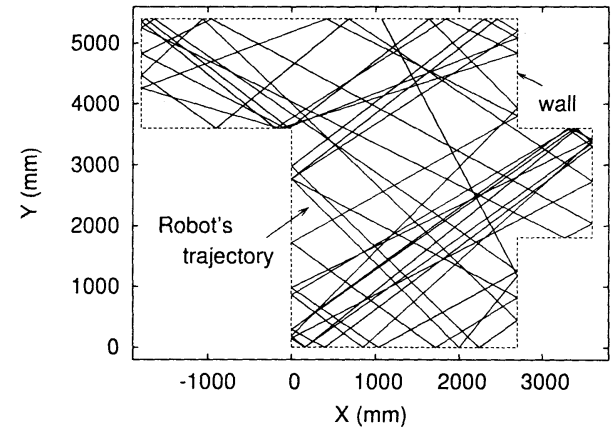

Fig. 9 Sample of robot's trajectory

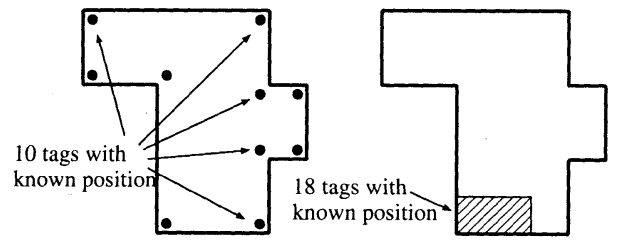

(a) wide and sparse pattern

(b) narrow and dense pattern

Fig. 10 Initial layout of already-known tags

$3 \cdot 2$ シミュレーション結果＼cjkstart実験は図 10 に示 す 2 つの初期状態で行った。 図 (a) は部屋の各角に, (b) は部屋の角の畳一枚分の上に位置既知のタグを配 置したものである.この部屋を一回清掃 (900m 散策) した時の結果を四 11 に示す。この図は隣接する夕グ を直線で結んで表示しており, 各交点が夕グ推定位置 となっている. タグは等間隔に配置されているため, 推定誤差は格子の歪みとなって現れる，既知の夕グを 含むテーブルとしての誤差 (真値との距離) の平均, 最 大及び標準偏差は (a) が $5.86 \mathrm{~mm}, 76.26 \mathrm{~mm}, 6.20 \mathrm{~mm}$, (b) が $15.85 \mathrm{~mm}, 43.54 \mathrm{~mm}, 8.35 \mathrm{~mm}$ であった。これ より既知のタグを広い範囲に配置した (a) の方が精度 が良いことが分かる，また，狭い範囲に密集して配置 した (b) でも，かなりの精度で夕グ位置を推定できて おり，特に既知のタグから一回の直進で到達できない 部屋の左上側や右中央側部分の下隅領域のタグも計測 されていることが分かる.この (b) の結果は, タグを 設置したマットを用意し，それを部屋の角に一時的に 置くことで, 環境内のタグの位置を計測することが可 能なことを示している.

ところで, タグの位置推定は一回の清掃作業 $(900 \mathrm{~m})$ で終える必要は無い，毎日の清掃作業を通じてタグ間 距離を蓄積し，推定することもできる，そこで散策距 離と, 得られた参照テーブルの大きさ,および参照テー

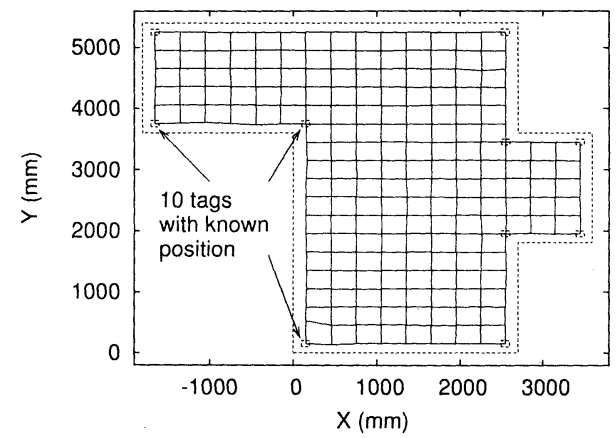

(a) Result on Fig. 10 (a) condition

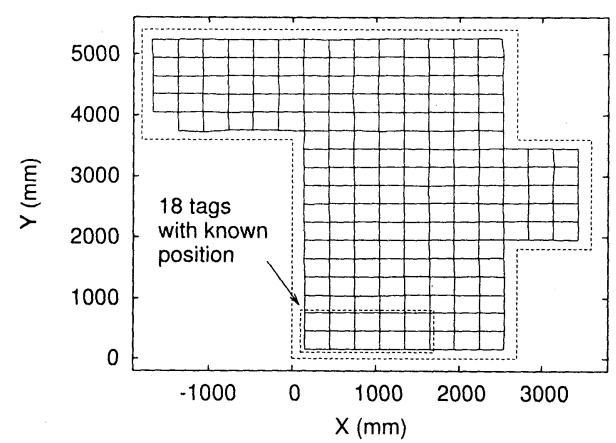

(b) Result on Fig. 10 (b) condition

Fig. 11 Obtained lookup table by simulation

ブルの平均誤差の関係を調べた. シミュレーションを 5 回行って得た参照テーブル 5 個の平均, 最大, 最小を 図 12 示す.この関係は部屋の広さに依存するが, 図 8 に示した部屋では, およそ $1800 \mathrm{~m}, 2$ 回の清掃で収束 することが分かる．また (a) の配置に比べ (b) は, 参 照テーブルのバラツキが大きいことも見て取れる。こ れは, 散策距離をさらに伸ばすと改善される考えられ るが，運用上は，タグ設置マット以外に数個の夕グを 遠隔地に配置した方が効果的と思われる。

3.3 誤差モデルの埒入 前節では，ロボット自 体の距離計測や直進性は誤差が無いと仮定していた。 しかし実際は, 床のうねりやロボットの寸法誤差等に より，ロボットの直進性や計測距離には誤差が含まれ ると予想される。これらの誤差がタグ埋設位置推定に どのような影響を与えるか調べるため, ロボットに夕 イヤ径を起因とした誤差モデルを導入し，図 10 (a)を 初期状態として, 散策距離 $1800 \mathrm{~m}$ でシミュレーション を行った。

直進性誤差は, 左右のタイヤ径のズレによって一定 の曲率 $R$ で前進すると仮定した。軌道の一例を図 13 に示す. 得られた参照テーブルの平均誤差と曲率との 


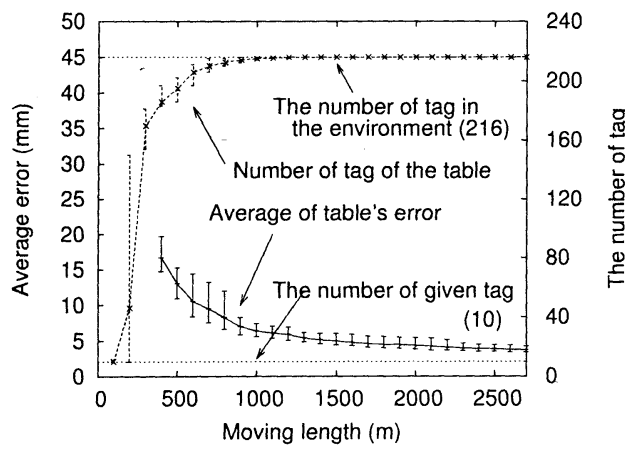

(a) on Fig. 10 (a) condition

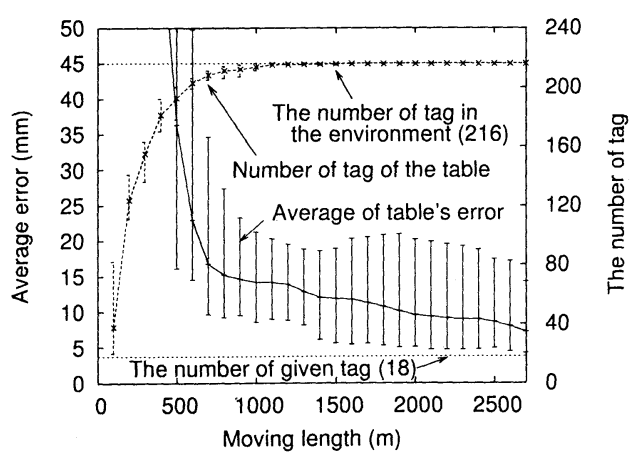

(b) on Fig. 10 (b) condition

Fig. 12 Relation between nomadizing distance of robot and tag localization

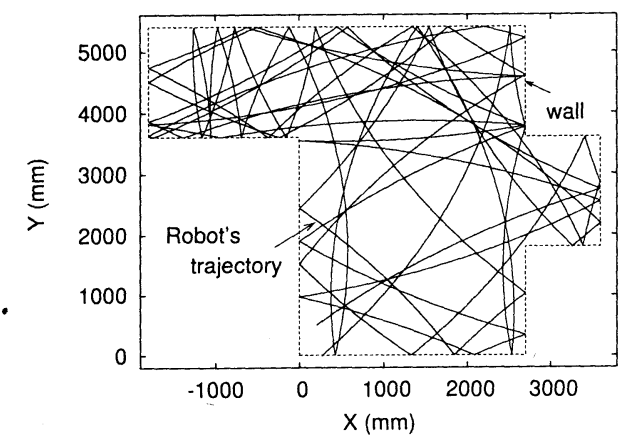

Fig. 13 Sample of robot's trajectory with curvature $=0.1$

関係を図 14 に示す。これより，曲率が $0.1(1 / \mathrm{m})$ 以 下では, ほとんど影響が無いことが分かる，安価なロ ボットでも, 左右の駆動輪に搭載されているエンコー ダとキャリブレーションによって, $0.1(1 / \mathrm{m})$ も誤差が

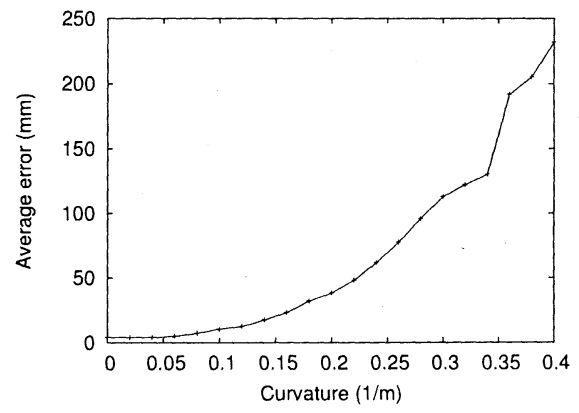

Fig. 14 Relation between tag localization and curvature of robot trajectory

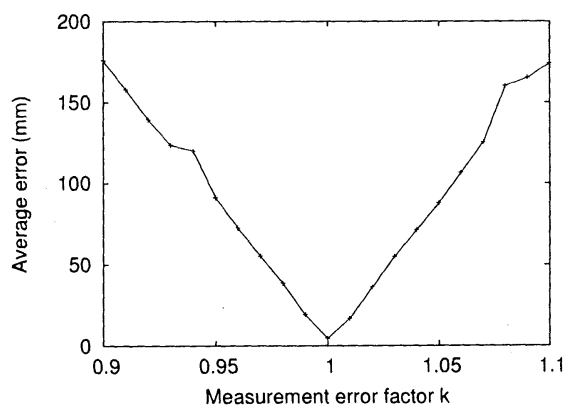

Fig. 15 Relation between tag localization and measurement error factor of distance

発生することはなく, 直進誤差の影響は無いと言える. ただし，この結果も部屋の広さに依存するため, 部屋 が十分に広いと, この曲率が問題になる可能性はある. これは，ある値以上の夕グ間距離を無視する処理をす ることで改善できる.

距離計測誤差は, 両輪のタイヤ径が設計値と異なっ たと仮定した. 実際の前進距離 $L$ に対し, 計測距離が $k L$ となった時の参照テーブルの平均誤差と $k$ の関係 を図 15 に示す，図のように計測距離のズレは位置推 定誤差に大きな影響を及ぼす。しかし，散策を通じ位 置既知のタグ同士の距離 $\bar{D}_{m n}$ も得られるため,

$$
k^{\prime}=\frac{\bar{D}_{m n}}{\left|\boldsymbol{X}_{m}-\boldsymbol{X}_{n}\right|}
$$

のように, リアルタイムに校正值を得ることができる. 実際にこの手法を用いて校正を行うと常に $k=1$ と 同程度の精度が得られるようになった。

なおここまでの議論では, タグの応答範囲は夕グを 中心とした円形になっていると仮定していた，しかし 実際は環境中の金属の影響を受け,夕グを中心としな 


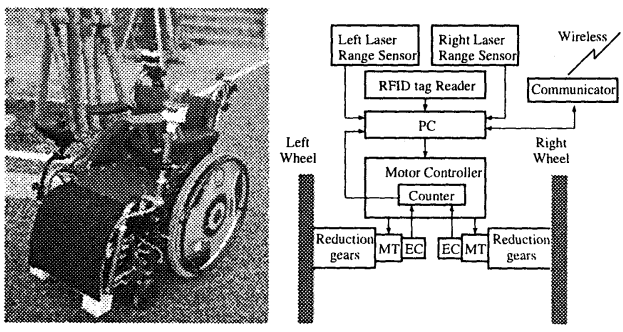

Fig. 16 Wheelchair robot

い非円形な応答範囲になることも考えられる。この場 合, $2 \cdot 2$ 節で述べたタグ間距離の計測に誤差が生じ, タ グの推定位置は, 埋設位置でなく応答範囲の重心にな る.ここで夕グの位置推定の目的は自己位置推定用の 参照テーブルを作ることである. 参照テーブルを利用 するロボットにとっては，タグの埋設位置より，応答 範囲の重心を得た方が都合が良い可能性もある。たた しこの可能性は, 個々のロボットに搭載されたリーダ の性能差による応答範囲の重心の違いや, 初めに埋設 した位置既知のタグが非円形の応答範囲を持つ場合な どを考慮すると, 常に成り立つわけではない.

\section{4 実機による検証図 16 に示す車椅子型口} ボットを用いて参照テーブルの構築実験を行った。こ のロボットは前面にレーザレンジセンサが搭載され ており，壁との近接を検知することができる。また 左右の駆動輪に取り付けられたエンコーダで進行距 離を $0.014 \mathrm{~mm}$ の分解能で得ることができる。広さ $3.5 \times 3 \mathrm{~m}$ の中に $250 \mathrm{~mm}$ 間隔でタグを埋設した部屋 で,タグの位置推定を行った，ただし，ロボットの大き さや安全を考慮し, 壁との距離に余裕を持たせ部屋の 中央 $2.25 \times 1.5 \mathrm{~m}$ にある 70 個の夕グのみ用いた.

2222 回の散策動作 (道程およそ $5000 \mathrm{~m}$ ) を通じ夕 グの位置推定を行った. 四隅の 16 個のタグ位置を与 えた時に得られた参照テーブルを図 17 に示す. 図に 示すように, 部屋の中央部分ではほぼ格子状に正しい タグ位置が推定されている。一方車椅子ロボットが転 回する壁際では誤差が大きくなっている. 平均誤差と 最大誤差はそれぞれ $18.1 \mathrm{~mm}, 105.0 \mathrm{~mm}$ であった。こ れより実機でも大まかな位置推定ができることが分か る.図 17 の中央部と周辺部とで明かな誤差の違いが 見て取れることから, 誤差の原因は, タグの応答半径 のバラツキに起因する測定距離に対する誤差よりも， 金属等の構造物の影響やロボットの動作の影響が大き いと考えられる．影響を与える要因として，床下の配 管等の金属の影響で応答範囲の中心と埋設位置がずれ たタグがあったこと, 厚いパイルのカーペット上で実

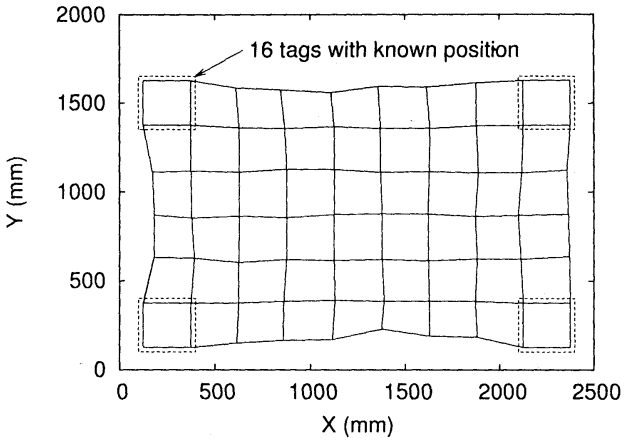

Fig. 17 Experimental result of tag localization by using a wheelchair robot

験を行ったためタイヤにすべりが生じたこと, 回転後 にロボットの前輪が進行方向を向かないまま前進し蛇 行したことなどが挙げられる.

今回の実験では, ほぼ一様な床環境にタグを設置し 実機の実験を行ったが，より広い環境では夕グの応答 半径のバラツキが誤差の原因として大きく占める可能 性もある.これについては, 応答範囲の異なる複数種 のタグを用いた実験を行うことで, 検証可能と考えら れる。

\section{4. 移動ロボットの位置推定による検証}

4.1 位置推定アルゴリズム 前章で得られた参 照テーブルは一定の誤差が含まれる。そこで, 1 章の シナリオ iii.の移動ロボットが誤差を含む参照テーブ ルを用いて位置推定を行うと, 自己推定位置にどの程 度の誤差が生じるか調べた。

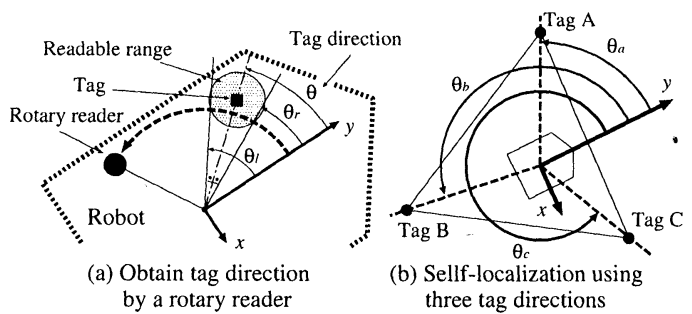

Fig. 18 Self-Localization method using a rotary tag reader proposed by $T$.Asakawa ${ }^{(6)}$.

1 章で述べたように, タグシステムを用いた位置推 定は様々な手法が検討されている.ここでは浅川ら ${ }^{(6)}$ が用いた回転式アンテナ (リーダ) を用いる手法を採 用する.この手法は, $2 \cdot 2$ 節で述べたようにタグ ID の 


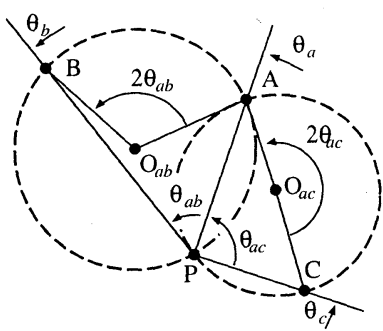

Fig. 19 Geometric localization using tag directions

読取れる範囲がタグを中心とした円状になっているこ とを利用し，図 18 (a) のようにリーダを円運動させ， タグが読取れ出した角度 $\theta_{r}$ と読取れなくなった角度 $\theta_{l}$ を二等分する方角 $\theta$ に夕グがあると考えるもので ある.浅川らは正三角形状に夕グを配置し，三つの夕 グの方角 $\theta_{a}, \theta_{b}, \theta_{c}$ から余弦定理とニュートン法を用 いて自己位置を得ていた (同図 (b)). しかし本論文で は，第三者が埋設したタグを利用するため，タグが正 三角形状に配置されていることは期待できない.そこ で, 図 19 のようにタグ A, B , C の推定位置を点 $\mathrm{A}$, $\mathrm{B}, \mathrm{C}$, リーダの回転中心 (自己位置) を点 $\mathrm{P}$ とし, 幾 何学的に点 $\mathrm{P}$ の位置を得た。

まず，夕グ $\mathrm{A}, \mathrm{B}$ の計測角度を $\theta_{a}, \theta_{b}$ とし, $\theta_{a b}=$ $\theta_{a}-\theta_{b}$ を定義する (ただし $0<\theta_{a b}<\pi$ ). 円周角の定 理により, 点 $\mathrm{P}$ は $\angle \mathrm{AOB}=2 \theta_{a b},|\mathrm{AO}|=|\mathrm{BO}|=R_{a b}$ を満たす点 $\mathrm{O}$ を中心とする半径 $R_{a b}$ の円周上に存在 する.この 2 つの条件を満たす点は平面上に 2 点存 在するが, $0<\theta_{a b}<\pi$ より点 $\mathrm{O}$ は一つに定まる.こ の点の座標 $O_{a b}$ と円の半径 $R_{a b}$ は, 夕グ $\mathrm{A}, \mathrm{B}$ の座 標 $\boldsymbol{X}_{a}, \boldsymbol{X}_{b}$ を用いて以下のように表すことができる.

$$
\begin{aligned}
& \boldsymbol{O}_{a b}=\frac{1}{2}\left\{\boldsymbol{X}_{\boldsymbol{b}}+\boldsymbol{X}_{\boldsymbol{a}}+\left(\begin{array}{rr}
0 & -1 \\
1 & 0
\end{array}\right) \frac{\boldsymbol{X}_{\boldsymbol{b}}-\boldsymbol{X}_{\boldsymbol{a}}}{\tan \theta_{a b}}\right\} \\
& R_{a b}=\left|\boldsymbol{O}_{a b}-\boldsymbol{X}_{a}\right|=\left|\boldsymbol{O}_{a b}-\boldsymbol{X}_{a}\right|
\end{aligned}
$$

これより点 $\mathrm{P}, \mathrm{A}, \mathrm{B}$ を円周上に持つ円を得ることがで きる. 同様にタグ $\mathrm{C}$ (点 $\mathrm{C}$ ) を用いて点 $\mathrm{P}, \mathrm{C}, \mathrm{A}$ を円 周上に持つ円を得ることができる．この二つの円の交 点は $\mathrm{P}$ と $\mathrm{A}$ である. 点 $\mathrm{A}$ の坐標は既知のため, 点 $\mathrm{P}$ の座標 $P$ を得ることができる.

ただし, 式 (8) より $\theta_{a b}$ が 0 や $\pi$ に近いと数値誤 差の影響が無視できなくなる.そこでタグ $\mathrm{AB}$ と $\mathrm{AC}$ の組合せの他に, $\mathrm{AB}$ と $\mathrm{BC}, \mathrm{AC} と \mathrm{BC}$ の組合せ 3 通 りに対し $\theta_{a b}, \theta_{a c}, \theta_{b c}$ が $5 \sim 175^{\circ}$ の時に限り点 $\mathrm{P}$ の 座標を計算し，それらの平均を取ることとした．また， リーダの円運動によって 3 個以上のタグが発見された

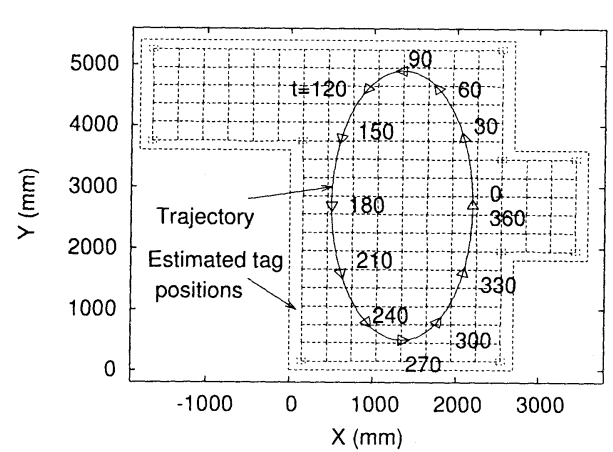

Fig. 20 Simulation condition of self-localization: lookup table and robot's trajectory

場合は, 3 個を取り出す組合せすべてに詨して同様に 点 $\mathrm{P}$ の位置を求め, すべての平均を推定位置とした。

一方，口ボットが向いている方向 (方位) $\phi$ は, 得 られた自己位置 $\boldsymbol{P}=\left(x_{p}, y_{p}\right)^{T}$ と夕グの位置 $\boldsymbol{X}_{a}=$ $\left(x_{a}, y_{a}\right)^{T}$, およびその夕グの観測角度 $\theta_{a}$ を用いて,

$$
\phi=\tan ^{-1} \frac{y_{p}-y_{a}}{x_{p}-x_{a}}-\theta_{a}
$$

を解いて得た. 今回は発見されたタグすべてに対して 方位を算出し，その平均を推定方位とした。

4.2 位置推定結果回転式リーダによる自己推 定位置は, タグの読取り周期とロボットの移動速度や リーダの回転速度の関係に依存する.また,リ一ダ角 の分解能や回転半径の影響も受ける.しかし,ここで はこれらを理想的な状態と扱い, シミュレーションで 自己位置推定能力を検証した.

シミュレーションは, リーダの回転半径を $400 \mathrm{~mm}$, 夕 グの応答半径を $90 \mathrm{~mm}$ と仮定し, 以下のように行った。

1. 夕グの埋設位置の真值を用い, ロボットの現在位 置から半径 $310 \sim 490 \mathrm{~mm}$ のドーナツ状の領域 にタグが存在していると, そのタグが読取れたと する。

2. 読取れたタグの検出角を真値を用いて幾何学的に 求める.

3. 得られた複数のタグの検出角と参照テーブルから, 前節の手法を用いて位置と方位の推定を行う. 一方ロボットは

$$
(850 \cos t+1350,2200 \sin t+2700)^{T}
$$

で表される棈円軌道を常に接線方向を向くよう移動さ せた， $t=1^{\circ}$ 毎に，図 12 (a) で得た距離 $1800 \mathrm{~m}$ の時 の結果を参照テーブルに用いて自己位置推定を行った。 


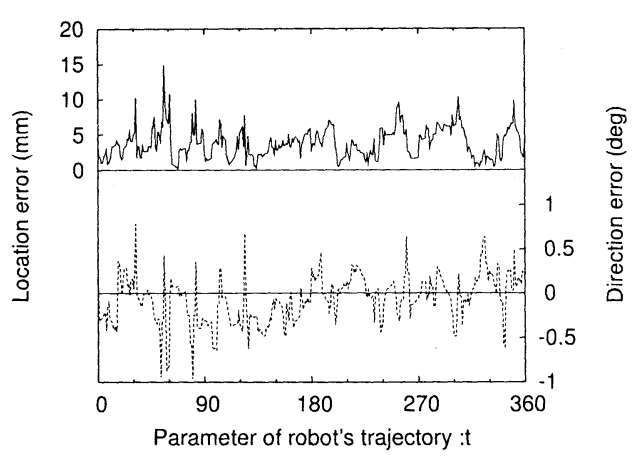

Fig. 21 Simulation result of self-localization by using rotary tag reader

参照テーブル (平均誤差 $4.16 \mathrm{~mm}$, 最大誤差 $16.02 \mathrm{~mm}$, 標準偏差 $2.81 \mathrm{~mm}$ ) とロボットの軌跡を図 20 に示す。

真値と推定值に対し, 位置は距離で, 角度は差を用 いて比較した結果を図 21 に示す. 図のように誤差が 含まれる参照テーブルを用いても，推定位置は $10 \mathrm{~mm}$ 以内, 推定方位は $1^{\circ}$ 以内で自己位置推定することが できた。これは, 移動ロボットの自己位置推定におい て十分な精度である。なお, 真値を参照テーブルに使っ た時の自己位置推定の結果は, 位置・角度共に常に 0 であった。

\section{5. まとめ}

環境内に埋設された配置不明の夕グを位置推定する 手法として, 自己位置推定機能の無い散策型ロボット を用いる方法を提案した。この手法は, 事前に知識と して少数のタグの埋設位置を与え, 散策でタグ間距離 を収集し，埋設位置推定を行うものである.シミュレー ション実験を行い, 本手法は平均誤差 $5 \mathrm{~mm}$ 以内で夕 グの位置推定ができることを示した，また, 計測ロボッ トの走行距離やロボットの走行誤差と, 得られるテ一 ブルの精度の関係を明らかにした．本手法を実ロボッ トでも検証し, 平均誤差 $18.1 \mathrm{~mm}$ の性能が確認された。 さらに, 得られた参照テーブルを用いて, 移動ロボッ トの自己位置推定シミュレーションを行った結果, 位 置精度 $10 \mathrm{~mm}$ 以内, 方位精度 $1^{\circ}$ 以内と実用上十分な 精度が得られることを確認した。

\section{謝辞}

本研究は文部科学省の平成 17 年度科学技術振興調 整費による、科学技術連携施策群の効率的・効果的な 推進」の一環として実施したものです.

\section{文献}

(1) Siio,I., User Position Detection using RFID Tags, "Information Processing Society of Japan" (ISSN:09196072), Vol.2000, No.19, (2000), pp.45-50

(2) D. Hähnel et al., Mapping and localization with RFID technology, "In Proc. of the 2004 IEEE Int. Conf on Robotics \& Automation", (2004) pp.10151020

(3) Tsukiyama,T., Navigation system for mobile robots using RFID tags. "In Proc. of the 11th Int. Conf. on Advanced Robotics", (2003) pp.1130-1135

(4) Yoshidome,T., et al, Measurement of Location and Direction Using IC Tags Applying to Indoor Navigation, "Proc. of the 2006 JSME Conf. on Robotics and Mechatronics", (2006), 2P2-A22

(5) Kashu,T., et al, Autonomous Trajectory Control Using RFID Landmark, "Proc. of the 2006 JSME Conf. on Robotics and Mechatronics", (2006), 2P2$\mathrm{E} 07$

(6) Asakawa,T. et al., A Detection System of Location and Direction Angle by a RF Tag Reader Using a Rotary Antenna, "Transactions of the Japan Society of Mechanical Engineers", Series C, Vol.73, No.729, (2007), pp.222-228

(7) Senta,Y. et al., Self-Localization for mobile robot using RFID tags without layout information "Jarnal of the Institute of Electrical Engineers of Japan", Vol.128-C, No.7 (2008), pp.1212-1221

(8) Senta,Y et al., Machine Learning Approach to SelfLocalization of Mobile Robots using RFID Tag, "Proc. of IEEE/ASME Int. Conf. on Advanced Intelligent Mechatronics", No. 136, (2007)

(9) Takarabe,S. et al., Self-Localization for Wheelchair robots using RFID Tags without Layout Information, "The 25th SICE Kyushu Branch Annual Conference", 102B4, (2006), pp.77-80

(10) Hada,Y. et al., Evaluation of Sweeping Performance of Commercial Home Cleaning Robot, "The 24th Annual Conference of the Robotics Society of Japan", (2006), 3E11 